\title{
Influence of Accounting Information Systems Directorate General of Taxes and Taxpayers Requirements for Tax Compliance Requirements (Research at the Foreign Investment Tax Office 5)
}

\author{
Endraria $^{1} \quad$ Achmad Bahiramsyah ${ }^{2}$ \\ 1.Lecturer at the Faculty of Economics and Business, University of Muhammadiyah Tangerang, Cikokol \\ Tangerang City Pioneer Independence Road I Banten Province Indonesia \\ 2.Post-graduate Faculty of Economics Study Program, Muhammadiyah University of Tangerang
}

\begin{abstract}
On going and sustainable activity that aims to increase the prosperity of the people both materially and spiritually is a National Development. To realize that goal, we need a lot of attention to the problems of development financing. One of the attempts to create an independence of a nation or country is to dig the source of fund which comes from domestic such as tax. ThereforeTax compliance is a significant problem throughout the world, both in developedcountries and in developing countries.Because if the taxpayer does not comply with the act willultimately lead to reduced state tax revenue, where the case could be caused by the DirectorateGeneral of Taxation Information System which is not going well and the implementation of e-SPTapplication programs are poorly understood taxpayer. The method of research using descriptive methods and verification. With a population of131 tax officials(95 male and 36 female), with a total sample of 71 tax officials, with sampling using purposive sampling,where the determination of the sample with certain considerations. Collecting data usingobservation,libraryresearch, questionnaires, and interviews. The results showed that the Information Systems Accounting Directorate General of Taxationsignificant effect on taxpayer compliance with the positive direction, which means the higher theInformation Systems Directorate General of Taxation then be better tax compliance. Similarly, fortheimplementation of e-SPT significantly influence taxpayer compliance with the positivedirection, which means the higher the e-SPT application of the tax compliance to be good. Thecoefficient of determination shows that together the Directorate General of Taxation InformationSystem and implementation of e-SPT application programs on tax compliance by $51.8 . \%$, Whilethe remaining $48.2 \%$ is influenced by other factors such as quality of service and socialization oftaxation regulations.
\end{abstract}

Keywords: Information Systems Directorate General of Taxation, e-SPT Taxawareness, Taxpayer Compliance DOI: $10.7176 / \mathrm{JESD} / 10-16-13$

Publication date: August $31^{\text {st }} 2019$

\section{Introduction}

Activities that take place continuously and continuously that aim to improve people's welfare both materially and spiritually are National Development. To be able to realize these goals need to pay much attention to the problem of financing development. One effort to realize the independence of a nation or state in financing development is to explore sources of funds originating from within the country in the form of taxes. Therefore, taxpayer compliance is an important issue throughout the world, both in majestic countries and in developing countries (Rahayu, 2010: 140). Because if the taxpayer does not obey it will lead to the desire to carry out acts of avoidance, circumvention, smuggling and tax disbursement which in the end the action will cause the state tax receipt will decrease (Rahayu, 2010: 140). Compulsory tax compliance is influenced by several factors, namely the condition of the state tax administration system, services to taxpayers, tax law enforcement, tax audit, and tax rates (Rahayu, 2010: 140). Various obstacles to tax compliance can be grouped into two, namely the internal factors of tax institutions, including tax regulations that may still be considered complicated, not simple in information technology support for taxpayer services and professionalism of human resources (HR) (Tjiptardjo, 2009). External factors can come from taxpayers and the environment that are not good so that taxpayers do not obey (Tjiptardjo, 2009). The use of Accounting information technology (SIA / SIDJP) is a must for every government agency, especially in an institution the size of a finance department (Jufri, 2010). In this globalization era, every agency is required to maximize all existing potential to achieve the targets set by the relevant agencies. In the Directorate General of Tax, information technology (SIA) used in relation to the performance of DGT is the Directorate General of Tax Information System or better known as SIDJP (Jufri , 2010). This Information System is an information system in tax administration within the DGT that is connected with a network of work in the head office (Jufri, 2010). Who will be able to monitor the behavior patterns of taxpayers who are already aware or not, so that the level of compliance can be measured by using SIDJP who are taxpayers who have not yet reported and who are aware, and who are taxpayers, tax bills (tax bills). STP) until a letter requesting an explanation of data 
or information (SP2DK). The main objective of the establishment of DGT information systems (SIA) is mainly expected to produce taxpayer profiles that can be a supporting tool for creating data and accurate taxpayers by mobilizing the participation of various parties in monitoring taxpayer data (TIP Directorate, 2019).

The problem with implementing this information system internally is that the information system is still not integrated. Development of Information Systems by vendors Technical networks are only focused on replacing the Tax Information System, there are problems with data migration from the Taxation / SIPModern Information System to SIDJP, Inefficiency of data processing and data redundancy, transfer of knowledge and SIDJP source code has not been done perfectly by the Technical Network (Upgrade each year). The Tax Directorate Directorate's Information System also has other disadvantages, namely when the workload is high, SIDJP's performance becomes sluggish (master server update) and of course slows down the new NPWP registration process or the SPT reporting process electronically, untilsupervision has an impact on taxpayer awareness (Putra , 2009). Taxpayer awareness can be carried out by the application of electronic SPT reporting (e-SPT) and for large taxpayers mandated in various countries (Cahyono, 2009). This system applies to all businesses regardless of how they conduct economic transactions (Cahyono, 2009). The Directorate General of Taxes (DGT), as the authorized party on this matter, knows exactly that the level of awareness of Taxpayers will be built with the ease of reporting transactions using the latest technology information systems. Therefore DGT always strives to provide convenience to taxpayers in reporting their SPT (Cahyono, 2009). One of the facilities to increase awareness given by DGT in this case is the provision of Electronic SPT applications (Cahyono, 2009).

Among the applications issued by SJP (e-SPT, e-Filling, e-Billing, e-Bupot) e-SPT application is a form of submitting SPT in electronic form made by Taxpayers using the e-SPT application provided by DGT (Cahyono, 2009). In reality, this system has made it easy for taxpayers to submit SPT electronically (Cahyono, 2009). But it cannot yet be ascertained whether the application of e-SPT can overcome all the weaknesses of the previous system and so that it can increase awareness and compliance of taxpayers (Cahyono, 2009). Even though e-SPT is one of the DGT's DGT's flagship programs there are still phenomena that occur in implementing e-SPT, for example tax payers knowlage who have not mastered information and technology (science and technology) for retirees (elderly people), if the load is full of central servers can be an error, in terms of installing applications and procedures for using e-SPT, taxpayers often do not know where an error has occurred because there are no instructions for using e-SPT (Novastria, 2014). From the above phenomenon explains that the implementation of SIDJP and the application of e-SPT in the field there are still things that must be corrected so as to cause taxpayers dissatisfaction and lack of awareness of taxpayers to carry out their tax obligations causing the compliance of taxpayers to decline. Conversely, if the implementation of SIDJP and the implementation of e-SPT are good and successful, taxpayers who have obligations will feel satisfied and certainly will increase awareness to the level of compliance of the taxpayer. Based on this explanation, the authors are interested in conducting research with the title influence of accounting information system (information system of general tax directorate) and awareness of tax-mandatory espt on compliance of foreign investment tax tax services reporting compliance. Problem Formulation. In accordance with the background of the above problems, the authors formulate the problems that will be discussed in this study are as follows: 1). Does the Accounting Information System Directorate General of Taxes (SIDJP) and the awareness of the Tax Authorities affect the compliance of taxpayers with Foreign Investment KPPs 5. 2). Does the application of e-SPT affect the taxpayer's compliance and awareness on the Foreign Investment KPP 5. 3). Is the Accounting Information System Directorate General of Taxes (SIDJP) and awareness of the application of e-SPT influential on mandatory compliance with Foreign Investment KPP 5. Research Objectives. The objectives of this study are as follows: 1). To find out whether the Directorate General of Taxation (Accounting) Information System (SIDJP) has an effect on taxpayer compliance with Foreign Investment KPPs 5. 2). To find out whether awareness of the application of taxpayer e-SPT has an effect on tax compliance on Foreign Investment KPP 5. 3). To find out whether the Information System (accounting) of the Directorate General of Taxes (SIDJP) and the application of e-SPT affect taxpayer compliance with Foreign Investment KPPs 5.

\section{Literature Review}

Definition of Accounting Information Systems / Directorate General of Taxes The following is a definition of the Directorate General of Tax Information System (SIDJP) based on SE-19 / PJ / 2007 are Accounting Information Systems is Information System of the Directorate General of Taxation is an information system for tax administration in the office of the modern Directorate General of Taxes by using hardware and software that is connected to a network at the head office. Information System Indicators Directorate General of Taxes. Based on the explanation above, the author determines the Accounting Information System / Directorate General of Tax indicators that will be used in this study, namely a). Software (Software), b). Human Resources (Brainware) c). Procedure / SOP (Procedure) d). Hardware (Hardware). Definition Of E-SPT And Awareness Of Taxpayers. In realizing a modern tax administration system, the government provides applications that can be used by taxpayers to fill and report SPT quickly, precisely and accurately so as to foster high awareness for taxpayers.E-SPT is the submission of digital tax return to KPP electronically or by using computer media (Pandiangan 2008: 35). Indicator 
e-SPT. Based on the explanation above, the authors determine the indicators of awareness of e-SPT which will be used in this study, namely: 1). Usage (use), 2) System quality (system quality), 3. User satisfaction (user statisfaction). Definition of Taxpayer Compliance. The definition of taxpayer compliance according to Minister of Finance Decree No.544 / KMK.4 / 2000 quoted by Sony Devano and SitiKurniaRahayu (2006: 112), states that :Actions of taxpayers in fulfilling their tax obligations in accordance with the provisions of laws and regulations and the implementation of taxation in force in a country. Taxpayer Compliance Indicators. Indicators of taxpayer compliance used in this study are: 1). The WP understands or attempts to understand all regulatory provisions taxation legislation, 2). Fill out the tax form completely and clearly, 3). Calculate the amount of tax owed correctly, 4). Pay the tax owed on time, 5). Report tax with awareness on time. Thinking Framework. Effect of the Directorate General of Tax Information System on Compliance Compliance Tax Supporting theory that connects according to Bird (1992: 22) which is translated by Ramdan (2006: 56) is as follows : Information and technology systems in security and protection of electronic data processes help taxpayers in reporting tax administration so that they save time on taxpayers and increase awareness and compliance of taxpayers can be increased.

Effect of the implementation of awareness of e-SPT on Taxpayer Compliance. The supporting theory that connects according to Rahayu (2009: 123) is as follows: The preliminary implementation of electronic SPT is an effort of the Director General of Taxes to provide ease of service for taxpayers in reporting the amount of tax that must be paid. Because taxpayers do not need to come directly to the Tax Service Office to fulfill their tax obligations in terms of SPT submission for Tax officials, this electronic technology is able to facilitate them in managing the database because the storage of Taxpayer documents has been done in digital form. The government hopes that with electronic technology it can increase the awareness and compliance of Taxpayers. "Because the easier people or agencies deliver, it does not require time, efficient distance and easy access wherever and when it will also raise awareness of taxpayers especially in using e-SPT where the digital era is taking place super fast internet access so there is no reason to not raise awareness of taxpayers and of course it will have a positive impact on compliance with the submission of annual tax returns for both individuals and agencies. Especially in the five foreign investment tax offices where each Tax is certain to use e-SPT because the taxpayers listed here all have the principle of overseas means that with all facilities, of course increasing the quality of awareness of registered taxpayers.

Hypothesis. According to Sugiyono (2011: 64) the definitions of hypotheses are as follows: The hypothesis is a temporary answer to the research problem formulation, where the research formulation has been expressed in the form of a statement sentence. Meanwhile, because the answers given are only based on relevant theories, they have not been based on empirical facts obtained through data collection. So the hypothesis is also expressed as a theoretical answer to the formulation of the research problem, not yet an empirical answer. Based on the description of the above framework, the writer tries to formulate the hypothesis as follows: $\mathrm{H}_{1}$ : Accounting Information Systems / Directorate General of Taxes affect compliance Taxpayer, $\mathrm{H}_{2}$ : The application of e-SPT awareness has an effect on Taxpayer Compliance, $\mathrm{H}_{3}$ : Directorate General of Tax Accounting Information System and Application of e-SPT awareness affects Taxpayer Compliance.

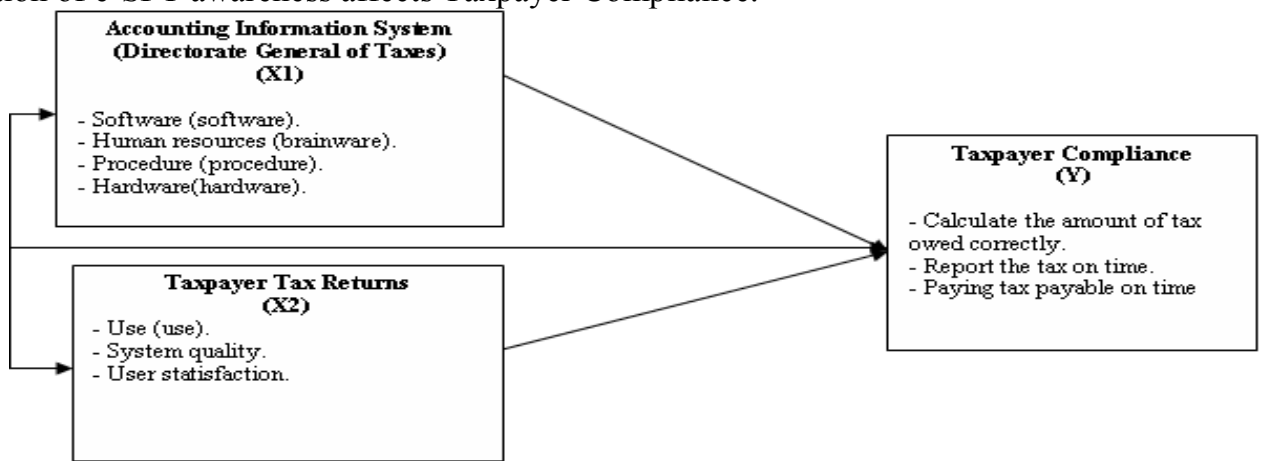

Figure 1. Research paradigm

\section{Research Method}

The object of research according to Husein Umar in Narimawati (2010:29) is as following The object of the study explains what and or who is the object of research, also where and when research is conducted, other things can also be added if considered necessary. In this study, the object of research is the Accounting Information System / Directorate General of Tax (SIDJP) research variables and the application of the e-SPT and the compliance with mandatory tax reporting. Research Methods. The research method used in this research is descriptive method and verification method. Definition of research methods according to Sugiyono (2011:2) are as follows: The research method is basically a scientific way to obtain data with specific purposes and uses. Research Design. According to Narimawati, et al. (2010: 30) states that research design as following: In conducting a study it is very necessary 
to do research planning and design, so that the research carried out can run well and systematically. According to Narimawati, et al. (2010: 30), the research design steps are as follows: 1) Establish the problem as an indication of the phenomenon of research, then set the research title; 2) Identifying problems that occur; 3) Establish the formulation of the problem; 4) Setting research objectives; 5) Establishing research hypotheses based on phenomena and theory support; 6) Establish the concept of variables as well as measuring variables used; 7) Establish data sources, sampling techniques, and data collection techniques; and 8) Reporting on research results. Operationalization of Variables. In conducting research, you must first determine the operational variables in order to make it easier to carry out the research, while understanding the operationalization of the variables according to Indriantoro (2012: 69) are as follows: Operationalization of variables is the determination of the construct so that it can be a variable that can be measured. Operational definitions describing certain ways can be used by researchers in operationalizing the construct, making it possible for other researchers to replicate measurements in the same way or develop better methods of measuring constructs. Variable operationalization is needed to determine the dimensions, indicators and scale of the variables involved in this study as for the variables involved in this study, namely: states that the variables are as follows: The research variable is basically something in the form of what is determined by the researcher to be studied so that information is obtained about it, then the conclusion is drawn. In accordance with the research title taken, namely X1 variable as independent (Accounting Information System Directorate General of Taxpayers (SIDJP)), X2 (implementation of e-SPT awareness) on Y variable as dependent (compliance with taxpayer reporting). Data Sources. The research activities that will be carried out are several methods that will be used in data collection. The methods used include making it easier in research to take a collection of data, namely: The definition of primary data according to Narimawati (2008: 98) explains that Primary data is data originating from the original or first source. This data is not available in compiled form or in the form of files. This data must be searched through the resource person or in the technical terms of the respondent, that is, the person we used as the object of research or the person we made as a means of obtaining information or data. Research Measurement Tools. Test Validity. According to Cooper in Narimawati (2010: 42), validity is Validity is a characteristic of measurement concerned with the extent to which a testmeures what the researcher actually wishes to measure. Validity test is done to find out whether the measuring instruments that have been designed in the questionnaire form can really carry out their functions. All items in the questionnaire must be tested for validity to determine whether an item is valid. One-sided validity was reached if the statement was able to reveal each statement with the number of scores for each variable.

Reliability Test. According to Cooper, quoted by Narimawati, et al. (2010: 43) Reality is as follows:"Reliability is a characteristic of measurement concerned with accuracy, precision, andconcistency".Reliability tests are carried out to test reliability and trust disclosure tools from data. Population and Sampling. According to Narimawati, et al. (2010:29), the population is defined as follows Population is an object or subject that has certain characteristics according to what was determined by the researcher as a research analysis unit. Based on this understanding, the population in this study are taxpayers of e-SPT users who are aware of and staff of the Foreign Investment Tax Office five whose numbers are equaled according to the number of Foreign Investment Tax Service Officers 5 to uniform the data of 67 taxpayers of e-SPT users and 67 Employees Foreign Investment Services Office 5. Samples. According to Sugiyono (2011: 81), states that Samples are part of the number and characteristics of the population. If a large population and researchers are not possible to learn all that exists in the population, for example due to limited funds, labor and time, the researcher can use samples taken from that population. What is learned from the sample, the conclusions will be applied to the population. For this reason, samples taken from the population must be truly representative. In this study the sample was chosen based on purposive sampling. According to Sugiyon, it is as follows Purposive sampling is a technique of determining samples with certain considerations. Data Collection Method. Data collection methods used in this study in two ways, namely Field Research and library research. Collection of primary and secondary data is done by 1). Field research a). Observation or observation method, namely the technique of collecting data by way of direct observation of the object being studied, observed or ongoing activities, b). Interview or interview, namely the technique of collecting data by giving questions to the parties related to the problem being discussed, c). Questionnaire, which is a technique of data collection carried out by giving a question or written statement to the respondent, 2). Library research (library research). This research is carried out through literature studies or literature studies by studying, researching, studying and analyzing literature in the form of books (text books), legislation, magazines, newspapers, articles, web sites and previous studies that have a relationship with the problem under study .

Design Analysis and Testing of Hypotheses. After the data collected the authors conducted an analysis of the data that has been described by using descriptive methods (qualitative) and verification (quantitative). 1). Descriptive Method. Descriptive research is a type of research that describes what is done by an institution based on the facts that are then processed into data. The data is then analyzed to obtain a conclusion. Descriptive research is used to describe how the Directorate General of Tax Information System influences and the application of eSPT to taxpayer compliance. 2). Verification Method. Verification research is research that is used to test 
hypotheses by using statistical calculations. This study was used to test the influence of independent variables $(\mathrm{X})$ on the dependent variable (Y) studied. Verification means testing the theory by testing a hypothesis whether accepted or rejected. The researcher analyzes the data that has been described using qualitative and quantitative methods. Qualitative Analysis. According to Sugiyono (2010:14) qualitative analysis is research method was carried out intensively, researchers participated in the field, carefully recorded what happened, carried out reflective analysis of various documents found in the field, and made detailed research reports. In this study to obtain more complete data from variables (Directorate General of Tax Information Systems) and (implementation of e-SPT), researchers used qualitative methods by interviewing resource persons from the relevant divisions. Quantitative Analysis. According to Sugiyono (2010:8) explains that quantitative analysis is Research methods based on the philosophy of positivism, are used to examine certain populations or samples, data collection using research instruments, quantitative / statistical data analysis, with the aim of testing the hypotheses that have been determined. The method used in this study is a quantitative method. Where the independent data collection (X1) Accounting Information System / Directorate General of Taxes (X2) the implementation of e-SPT Awareness collected through questionnaires still has an ordinal scale, then before it is processed and compared with dependent variable data (Y) taxpayer reporting compliance, ordinal data is first converted to interval data using the Method of Successive Interval (MSI). 1). Test of Classical Assumptions. Testing the presence or absence of violations of classical assumptions that are fundamental in multiple linear regression models. a) Normality Test. The normality test is used to test whether the regression model has normal distribution or not. b) Multicollinearity Test. Multicollinearity is a situation where several or all independent variables are strongly correlated. c) Heterocedasticity Test. The assumption of heterocedasticity is a regression assumption where the variance of residuals is not the same for one observation to another 2). Analysis of Multiple Linear Regression. According to Sugiyono (2010: 149) linear regression analysis is used to predict how changes in the value of the dependent variable if the value of the independent variable is increased or lowered. In this study, multiple linear regression analysis was used to prove to what extent the relationship between the Accounting Information System / Directorate General of Taxes and the implementation of e-SPT awareness on taxpayer reporting compliance. 3). Correlation Analysis. Correlation analysis aims to measure the strength of linear associations (relationships) between two variables. Correlation also does not show functional relationships. In other words, correlation analysis does not distinguish between the dependent variable and the independent variable. From the regression analysis, the correlation analysis used also shows the direction of the relationship between dependent variables and the independent variable other than measuring the strength of the association (relationship). 4). Coefficient of Determination. Determination Coefficient Analysis (Kd) is used to see how much the independent variable (X) affects the dependent variable (Y) expressed in percentages.

Hypothesis Test. Based on the identification of the problems stated earlier, then in this study the authors submit the following hypothesis: 1). Partial hypothesis between independent variables of Accounting Information Systems / Directorate GeneralTax on the dependent variable of taxpayer compliance. Ho: There is no significant influence between the Accounting Information System / DirectorateGeneral of Taxes on taxpayer compliance. Ha: There is a significant influence between the Accounting Information System / Directorate GeneralTax on taxpayer compliance. 2). Partial hypothesis between the independent variables of the application of e-SPT awareness to variablesbound to compliance with taxpayer reporting. Ho: There is no significant influence between the application of e-SPT awareness to taxpayer reporting compliance. Ha: There is a significant influence between the application of e-SPT awareness tocompliance reporting required tax. 3). The overall hypothesis between independent variables is Information Systems Accounting Directorate General of Taxes and the application of awareness of e-SPT to taxpayer reporting compliance. Ho: There is no significant influence between the Accounting Information System / DirectorateGeneral of Taxes and the application of e-SPT awareness to compliance with mandatory reportingtax. Ha: There is a significant influence between the Accounting Information System / Directorate General of Taxes and the application of e-SPT awareness to compliance with mandatory reporting tax.

Statistical Hypothesis. Testing Hypotheses Partially (Test Statistic t). In testing this hypothesis using a twoparty test (two tail test) seen from the sound of the statistical hypothesis that is the null hypothesis $(0): \beta=0$ and the alternative hypothesis $(\mathrm{Ha}): \beta \neq 0$ : Ho: $\beta=0$ : There is no significant influence between Accounting Information Systems Directorate General of Taxes on compliance with taxpayer reporting. Ha: $\beta \neq 0$ : There is a significant influence between the Accounting Information System Directorate General of Taxes for compliance with taxpayer reporting. o: $\beta=0$ : There is no significant influence between the application of SPT awareness towards compliance with taxpayer reporting. Ha: $\beta \neq 0$ : There is a significant influence between the application of e-SPT awareness totaxpayer reporting compliance. Simultaneous Hypothesis Testing (Test Statistic F). Ho: $\beta=0$ : There is no significant influence between the Accounting Information System /Directorate General of Taxes and the application of e-SPT awareness to compliancetaxpayer reporting. Ha: $\beta \neq 0$ : There is a significant influence between the Accounting Information System / DirectorateGeneral of Taxes and the application of e-SPT awareness to compliance reporting tax payer. 
Table 1. Variable Operationalization

\begin{tabular}{|c|c|c|c|c|c|}
\hline Variable & Variable Concept & Dimension & Indicator & Numbers & Scale \\
\hline \multirow{4}{*}{$\begin{array}{l}\text { Information } \\
\text { System of } \\
\text { the } \\
\text { Directorate } \\
\text { General of } \\
\text { Taxpayers } \\
\text { (SID JP) } \\
\text { (X1) }\end{array}$} & \multirow{4}{*}{$\begin{array}{l}\text { The Directorate General of } \\
\text { Tax Information System is a } \\
\text { tax administration } \\
\text { information system in the } \\
\text { office of the modern } \\
\text { Directorate General of } \\
\text { Taxes using hardware and } \\
\text { software associated with a } \\
\text { network at the central office. } \\
\text { (SE-19/PJ / 2007) }\end{array}$} & 1. Software & 1. Supporting devices & 2 & \multirow{4}{*}{ Ordinal } \\
\hline & & 2. Brainware & $\begin{array}{l}\text { 3. Understanding of } \\
\text { SIDJP }\end{array}$ & 3 & \\
\hline & & 3. Prosedur & $\begin{array}{l}\text { 4. Standard Operating } \\
\text { Procedure }\end{array}$ & 4 & \\
\hline & & 4. Hardware & 5. Supporting devices & 1 & \\
\hline \multirow[t]{3}{*}{$\begin{array}{l}\text { E-SPT } \\
\text { Awareness } \\
(\mathrm{X} 2)\end{array}$} & \multirow{3}{*}{$\begin{array}{l}\text { Notification letters along } \\
\text { with attachments in digital } \\
\text { form and reported } \\
\text { electronically or by using } \\
\text { computer media used to } \\
\text { assist taxpayers in reporting } \\
\text { the calculation and payment } \\
\text { of tax payable in accordance } \\
\text { with the provisions of the } \\
\text { applicable legislation } \\
\text { (Directorate General of } \\
\text { Taxes). }\end{array}$} & 2. use & $\begin{array}{l}\text { Ease of use } \\
\text { User understanding } \\
\text { Effectiveness of the } \\
\text { application }\end{array}$ & $\begin{array}{l}1 \\
2 \\
6\end{array}$ & \multirow{3}{*}{ Ordinal } \\
\hline & & $\begin{array}{l}3 . \quad \text { system } \\
\text { quality }\end{array}$ & $\begin{array}{l}\text { 1. Help } \\
\text { 2. Network connection } \\
\text { 3. System stability }\end{array}$ & $\begin{array}{l}3 \\
5 \\
4\end{array}$ & \\
\hline & & $\begin{array}{l}4 . \quad \text { user } \\
\text { statisfication }\end{array}$ & $\begin{array}{l}\text { 1. Level of user } \\
\text { satisfaction }\end{array}$ & 7 and 8 & \\
\hline \multirow[t]{5}{*}{$\begin{array}{l}\text { "Compliance } \\
\text { Mandatory } \\
\text { Tax (Y)" }\end{array}$} & \multirow[t]{5}{*}{$\begin{array}{l}\text { A situation where the } \\
\text { taxpayer fulfills formal } \\
\text { obligations in accordance } \\
\text { with the provisions of the } \\
\text { tax law (Rahayu, 2009) }\end{array}$} & $\begin{array}{l}\text { Taxpayers } \\
\text { Understand } \\
\text { all tax } \\
\text { provisions }\end{array}$ & $\begin{array}{l}\text { Understanding of } \\
\text { taxpayers about taxation } \\
\text { systems } \\
\text { Understanding } \\
\text { taxpayers with the } \\
\text { existence of SIDJP }\end{array}$ & 13 & \multirow{5}{*}{ Ordinal } \\
\hline & & $\begin{array}{l}\text { Complete the } \\
\text { tax form } \\
\text { completely } \\
\text { and correctly }\end{array}$ & $\begin{array}{l}\text { Fill in the SPT } \\
\text { according to the rules }\end{array}$ & 6 & \\
\hline & & $\begin{array}{l}\text { Calculate the } \\
\text { amount of tax } \\
\text { owed } \\
\text { correctly }\end{array}$ & $\begin{array}{l}\text { The accuracy of } \\
\text { calculating tax payable }\end{array}$ & 8 & \\
\hline & & $\begin{array}{l}\text { Paying tax } \\
\text { payable in a } \\
\text { timely } \\
\text { manner }\end{array}$ & $\begin{array}{l}\text { Timely payment of } \\
\text { payable taxes }\end{array}$ & 7 & \\
\hline & & $\begin{array}{l}\text { Report tax on } \\
\text { time }\end{array}$ & $\begin{array}{l}\text { Timeliness of reporting } \\
\text { Timeliness of reporting } \\
\text { with the e-SPT } \\
\text { application } \\
\text { The e-SPT application } \\
\text { makes the tax reporting } \\
\text { process easier } \\
\text { Timeliness of reporting } \\
\text { with the presence of } \\
\text { SIDJP }\end{array}$ & 5 & \\
\hline
\end{tabular}

\section{IV.Analysis And Discussion}

Effect of the Accounting Information System / Directorate General of Taxes on Compliance with Compulsory Reporting The results of the regression coefficients for the Accounting Information System / Directorate General of Taxes are 0.899, meaning that when the Accounting Information System / Directorate General of Taxes 
increases, the application of e-SPT awareness is constant, compliance reporting taxpayers will settle at 0.889 . The results of the correlation values obtained between the Accounting Information System / Directorate General of tax with compliance with taxpayer reporting amounted to 0.440 . The correlation value is positive, which indicates that the relationship that occurs between the Accounting Information System / Directorate General of Taxes with compliance with taxpayer reporting is in the same direction. Where the higher the Accounting Information System / Directorate General of Taxes, the better the compliance of taxpayer reporting will be followed. Based on the interpretation of the correlation coefficient, a value of 0.440 is included in the category of moderate relationships, in the interval range between 0.400 to 0.599 . The results of the coefficient of determination of the Accounting Information System / Directorate General of Taxes have an effect of $20.9 \%$ which means that the Accounting Information System / Directorate General of Taxes has a significant effect of $20.9 \%$ on compliance with taxpayer reporting on Foreign Investment Tax Services five while the remaining $48,2 \%$ is influenced by other factors not examined such as the quality of service, socialization of tax regulations, tax regulation policies, tax intensification.

The results of testing the hypothesis of tcount for Accounting Information Systems / Directorate General of tax 5.032 in the rejection area $\mathrm{HO}( \pm 2.005)$ so that in accordance with the criteria testing the hypothesis is to reject H0 and accept Ha, which means there is a significant effect between the Accounting Information System / Directorate General of Tax compliance taxpayer reporting at the Foreign Investment Service Office five. Based on the results of the verification analysis it can be concluded that the Accounting Information System / Directorate General of Taxes affects the compliance of taxpayer reporting, according to the results of the ArifRamdan (2006) study which shows that the Accounting / Taxation Information System provides a positive influence on taxpayer reporting compliance. While the Accounting Information System / Directorate General of Taxes obtained a percentage of $77.8 \%$ in the criteria of good, but the network connection indicator is still in a fairly good category with the percentage value obtained at $65.6 \%$. This shows that the network connection in the Foreign Investment Tax Service Office five has not functioned well to run the Accounting Information System / Directorate General of Taxes and answer the phenomenon that when the workload is high then the Information System performance The Directorate General of Taxes is slow or even hangs and slows down the process of registering new NPPPs or the SPT reporting process electronically (Putra, 2009).

Effect of the application of e-SPT awareness on Taxpayer reporting compliance The results of the regression coefficients for the implementation of e-SPT awareness amounted to 0.954, meaning that the e-SPT awareness implementation has temporarily increased the Accounting Information System / Directorate General of Taxes, then compliance with taxpayer reporting will increase by 0.954 . The results of the correlation values obtained between the application of awareness of e-SPT and compliance with taxpayer reporting amounted to 0.541 . The correlation value is positive, which indicates that the relationship that occurs between the application of e-SPT awareness and compliance with taxpayer reporting is in the same direction. In addition, the higher the application of awareness of e-SPT, the better compliance of compulsory tax reporting will be followed. Based on the interpretation of the correlation coefficient, a value of 0.541 is included in the category of moderate relationships, in the interval range between 0.400 to 0.599 .

The results of the coefficient of determination of the application of e-SPT awareness have an effect of $30.9 \%$, which means that the implementation of e-SPT awareness has a significant influence of 30.9\% on taxpayer reporting compliance at the five-temporary Foreign Investment Tax Office at $48.2 \%$ influenced by other factors not examined such as tax regulation socialization, service quality, tax regulation policies, and tax intensification. The results of hypothesis testing of the tcount for the application of e-SPT awareness are 6.043 in the rejection area of $\mathrm{HO}( \pm 2.005)$ so that according to the hypothesis testing criteria is to reject $\mathrm{H} 0$ and accept Ha, which means that there is a significant influence on e-SPT awareness on taxpayer reporting compliance with Five Foreign Investment Office. Based on the results of the verification analysis it can be concluded that the application of eSPT awareness influences taxpayer reporting compliance, in accordance with the results of the study of Supadmi (2013) showing that the implementation of e-SPT awareness has a positive influence on taxpayer reporting compliance. Where as the application of e-SPT awareness obtains a percentage of $58.5 \%$ in the criteria is quite good, but the system stability indicators are in a poor category with the percentage value obtained is $49.8 \%$. This shows that the system stability in the e-SPT application program has not functioned properly to implement the implementation of e-SPT awareness and answers the phenomenon that when taxation often experiences problems, for example in terms of installing applications and procedures for using e-SPT, taxpayers often do not know where an error has occurred because there are no instructions for using e-SPT (Novastria, 2014).

Effect of the Accounting Information System / Directorate General of Taxes and the Implementation of eSPT awareness of Taxpayer reporting compliance The results of the constant regression coefficient of -6.105 state that when the Accounting Information System / Directorate General of Taxes and the implementation of awareness e-SPT is 0 (zero) and there is no change, then compliance with taxpayer reporting will be worth -6.105 . The results of the simultaneous correlation value of the simultaneous correlation coefficient obtained between the Accounting Information System / Directorate General of Taxes and the application of e-SPT awareness with compliance with mandatory tax reporting is 0.720 . The correlation value is positive which shows that the relationship between the 
two independent variables with the dependent variable is in the same direction. Where the better the Accounting Information System / Directorate General of Taxes and the application of e-SPT awareness, the higher compliance of taxpayer reporting will be followed by the five Foreign Investment Tax Service Offices. Based on the interpretation of the correlation coefficient, a value of 0.720 is included in the strong relationship category, in the interval between $0.600-0.799$. Based on the results of the coefficient of determination, it can be concluded that the two independent variables consisting of Accounting Information Systems / Directorate General of Taxes and the implementation of e-SPT awareness give contribution to compliance with taxpayer reporting of $51.8 \%$, while $48.2 \%$ of students are contributions from other variables which is not examined. From the results of the calculation of the coefficient of determination, it can be seen that the application of e-SPT awareness contributes the most to the compliance of taxpayer reporting by $30.9 \%$, while the other $20.9 \%$ is given by the Accounting Information System / Directorate General of Taxes.

The results of hypothesis testing obtained information that the Fcount obtained for 29.107 was in the area of rejection $\mathrm{HO}( \pm 3.168)$ so that it corresponds to the hypothesis testing that $\mathrm{H} 0$ is rejected and Ha is accepted, meaning that both independent variables consist of Accounting Information Systems / Directorate General of Taxation and implementation e-SPT awareness has a significant effect on compliance with taxpayer reporting at the Foreign Investment Tax Service Office 5. Where as Taxpayer reporting compliance obtains a percentage of $73.7 \%$ in good criteria, but the Taxpayer's understanding of taxation and SPT filling according to the rules is still in a fairly good category with the percentage value obtained at $55.8 \%$ and $66 \%$. This shows that the understanding of mandatory taxation and filling in tax returns is according to the rules. Taxpayers at the Foreign Investment Tax Service Office five do not run well to support taxpayer reporting compliance and answer the phenomenon that not all Taxpayers fulfill taxation requirements (Budiono, 2003).

\section{Conclusion}

Based on the results of research on Accounting Information Systems / Directorate General of Taxes and the implementation of awareness of e-SPT on compliance with taxpayer reporting, conclusions can be drawn as follows:

1) The Accounting / Directorate General of Tax Information System (SIDJP) has a positive and significant influence on taxpayer reporting compliance while the rest is influenced by other factors such as service quality, tax regulation socialization, taxation policies, and tax intensification. There is a strong connection between the Accounting Information System / Directorate General of Taxes and compliance with mandatory tax reporting. This means that if the Accounting Information System / Directorate General of Taxes increases the compliance of taxpayer reporting will increase. The Accounting Information System / Directorate General of Taxes on Foreign Investment Investment Tax 5 includes in the good category.

2) The implementation of e-SPT awareness has a positive and significant influence on compliance with mandatory tax reporting while the remainder is influenced by other factors such as service quality, socialization of tax regulations, tax regulation policies, and tax intensification. There is a strong relationship between the application of e-SPT awareness and compliance with taxpayer reporting. This means that if the application of e-SPT awareness increases, compliance with taxpayer reporting will increase. The Accounting Information System / Directorate General of Taxes on Foreign Investment KPPs is included in the fairly good category.

3) Accounting Information Systems / Directorate General of Taxes (SIDJP) and the application of SPT awareness give a positive and significant influence on compliance with taxpayer reporting where there is a strong relationship, but the relationship between the application of SPT awareness to taxpayer report compliance is more dominant than the relationship between Accounting Information Systems / Directorate General of Taxes on compliance with taxpayer reporting at the Foreign Investment Tax Office five.

\section{VI.Suggestions}

Based on the conclusions that have been stated regarding the Accounting Information System / Directorate General of Taxes and the application of e-SPT awareness to the compliance of taxpayer reporting, the researchers provide suggestions as consideration and can be used as input to Foreign Investment Tax Services 5 as follows:

1) Most of the respondents in the Foreign Investment Tax Service Office five argue that the Accounting Information System / Directorate General of Taxes can increase compliance with taxpayer reporting, therefore if possible it is best for the Foreign Investment Tax Service Office to improve and improve network connectivity in the Accounting Information System / Directorate General of Taxes by updating hardware (hardware) so that there is no 'hang' or "lag" when the workload of computers and systems is getting higher, updating software (software) that is as easy as possible for employees to understand so as not to hamper the implementation of Accounting Information Systems / Directorate General of taxes so that compliance with taxpayer reports can be increased.

2) Most of the respondents in the Foreign Investment Tax Service Office found that the application of SPT 
awareness can improve taxpayer reporting compliance, because it is possible if possible the Foreign Investment Tax Service Office can further stabilize the system in the e-SPT application by updating the system from the application e-SPT so that taxpayers can more easily use the e-SPT application both in terms of e-SPT application software and usage procedures from installation to tax report making so that compliance with taxpayer reports can increase.

3) Most of the respondents in the Primary Tax Service Office of Foreign Investment five argue that the Accounting Information System / Directorate General of Taxes and the implementation of awareness of eSPT can improve compliance with taxpayer reporting, therefore it is recommended that the Office of Tax Services Foreign Investment more refining the Accounting Information System / Directorate General of Taxes applying e-SPTagar makes it easier to report taxpayers in terms of carrying out their tax obligations in accordance with the provisions and to increase the awareness of taxpayers in fulfilling their tax obligations and will directly increase compliance of taxpayers.

\section{Refrences}

James, Brian \& Jonathan. 1998. Tax Compliance. Journal of Economic Literature.Vol. 36. NO.2. pp. 818-860

Eko. 2003. Implementation of a Simple Examination in the Context of Safeguarding the Acceptance of Value Added Taxes. Faculty of Economics, Muhammadiyah University.Sidoharjo.

Louis L. 1988. An Empirical Analysis of Federal Income Tax Auditing and Compliance.National Taxation. Journal.vol. 41.pp.61-74

Tamboto. 2013. Effect of Application of PPN e-SPT on the efficiency of filling in VAT SPT According to the Taxable Entrepreneurs Perception at Manado Primary Tax Office. EMBA Journal. Vol.1 No.4 Page 20592068.

Jackson \& McKee. 1992. Estimating the Determinants of Taxpayer Compliance with Experimental Data. National Tax Journal.45 (March). 107-114.

Ramdan. 2006. Effect of Tax Information System on Taxpayer Compliance and Tax Receipts at Corporate. Tax Offices and Foreigners One by Taxpayers.

Roy, Murray \& Matthew N. 1990. Tax Structure and Tax Compliance. The Review of Economics and Statistics. Vol. 72. NO.4. (Nov. 1990). pp. 603-613.

Barker et al. 2002. Research Methods In Clinical Psychology. John Wiley \& Sons Ltd. England.

James. 1991. A Perspective on the Experimental Analysis of Taxpayer Reporting. The Accounting Review.Vol. 66.NO.3. (July). pp. 577-593

Putra. 2009. Directorate General of Tax Information System.

Cahyono. 2009. Electronic SPT (e-SPT).

Handayani \& Supadmi. 2013. Effect of Effectiveness of VAT Period e-SPT on Corporate Taxpayer Compliance at West Denpasar Primary Tax Office.

Mashuri. 2008. Verification research. First edition.Andi.Yogyakarta.

Pandiangan. 2008. Modernization and Reform of Tax Services. PT ElexMediaKomputindo. Jakarta.

Nazir. 2003. Research Methodology. SalembaEmpat. Jakarta.

Indriantoro \& Supomo. 2002. Business Research Methodology. Second print. BPEE UGM. Yogyakarta.

Muhammad Jufri. 2008. E-registration Tax Not Interested.

Bird \& Jantscher. 1992 Improving Tax Administration Developing Countries. Washington D.C. The IMF.

Gujarati. 2003. Basic Econometrics. 4 ed. McGraw-Hill Companies, Inc. New York.

Novastria. 2014. Massive breakthrough of Period e-SPT of Article 21 Income Tax.

2012. Strategies to Improve Taxpayer Compliance.

Sugiyono. 2009. Quantitative and Qualitative Research Methods and $R \& D$. Alfabeta. Bandung.

Santoso. 2002. SPSS 10 Processes Statistical Data Professionally. PT ElexMediaKomputindo. Jakarta.

......... 2007. SPSS Parametric Statistics Exercise Book. PT Elex Media Komputindo.Jakarta.

Rahayu. 2010. Indonesian Taxation: Concepts \& Formal Aspects. GrahaIlmu. Yogyakarta.

Devano \& Rahayu. 2006. Taxation: Concepts, Theories, and Issues. One. Jakarta

Rahayu. 2009. Effect of Modernization of the Tax Administration System on Taxpayer Compliance. Journal of Accounting Vol. 1 No. 2 Maranatha University Press. Bandung.

Indrayanto. 2017 Journal of The Influence of the Directorate General of Tax Information System and Implementation of E-Spt on Taxpayer Compliance.

Sugiyono. 2011. Quantitative and Qualitative Research Methods and $R \& D$. Alfabeta. Bandung.

Arikunto. 2006. Research Procedure A Practice Approach. RinekaCipta. Jakarta.

Sekaran. 2006. Research Methodology for Business. Edition 4.Book 1.SalembaEmpat. Jakarta.

Narimawati. 2007. Human Resource Management Research. Supreme Media. Jakarta. 2008. Qualitative and Quantitative Research Methodology, Theory and Application. GreatMedia. Bandung. 
2010. Scientific Writing: An Initial Guide to Writing Thesis and TasksEnd. Genesis. Jakarta. Santoso. 2008. Analysis of the Risk of Non-compliance of Taxpayers as a Basis for Improving Taxpayer Compliance. Public Finance Journal. Vol.5 No.1 Page 85-137.

Ann D. \& Diane F. 1985. The Effect of Tax Laws and Tax Administration onTax Compliance: The Case of the u.s. Individual Income Tax. National Taxation Journal.vol.38. pp. 1-13

www.tax.go.id

www.ortax.go.id 